\title{
STRATEGI PEMBERDAYAAN KELEMBAGAAN DESA: STUDI KASUS DI DESA NAGARAWANGI, KECAMATAN RANCAKALONG, KABUPATEN SUMEDANG
}

\author{
Endah Dwi Winarni \\ Politeknik Kesejahteraan Sosial Bandung, endah_dwiwinarni@yahoo.co.id
}

\begin{abstract}
Changes in the environment due to the development of information technology, digitalisation, and globalization have made villages demanded to be responsive and adaptive without losing their characteristic values. Several studies have suggested that village institutional capacity is important in dealing with the above situation. Thus, this study discusses the institutional capacity of the village in dealing with challenges in the contemporary era. This research argues that it is important to develop a village institutional empowerment strategy for rural development and development in the contemporary era. The results of this study are the existence of various forms of institutional constraints and forms of empowerment programs that are categorized in three aspects, namely HR (individual) governance, organizational (group) governance, and supervision (community). The conclusion of this research is to touch all levels in the mechanism of institutional empowerment, both at the individual, group and community levels, to be able to grow the structure and culture of village institutions that are transparent, accountable, professional, and responsive in order to realize the welfare of an independent and sustainable village community. This research suggests, in the nearest future, practicing an empowerment program in an individual level that is able to address the issue of "responsibility of village institutional personnel" because it is more fundamental in terms of the complexity of the issue, number of stakeholders, and funding. This study uses qualitative approach with a case study in Nagarawangi Village, Rancakalong District, Sumedang Regency.
\end{abstract}

Keywords:

village institutions, village empowerment, village development.

\begin{abstract}
Abstrak
Perubahan lingkungan akibat berkembangnya teknologi informasi, adanya digitalisasi, dan globalisasi membuat desa dituntut agar responsif dan adaptif tanpa kehilangan nilai-nilai karakteristiknya. Beberapa penelitian menyampaikan bahwa kapasitas kelembagaan desa menjadi hal penting guna menghadapi situasi di atas. Dengan demikian, penelitian ini membahas tentang kapasitas kelembagaan desa dalam menghadapi tantangan-tantangan di era kontemporer. Penelitian ini berargumen pentignnya menyusun strategi pemberdayaan kelembagaan desa guna pengembangan dan pembangunan desa di era kontemporer. Hasil penelitian ini adalah adanya beragam bentuk kendala kelembagaan dan bentuk program pemberdayaan yang dikategorikan dalam tiga aspek, yaitu tata laksana SDM (individu), tata laksana organisasional (kelompok), dan pengawasan (komunitas). Kesimpulan penelitian ini adalah dengan menyentuh seluruh jenjang dalam mekanisme pemberdayaan kelembagaan, baik jenjang individu, kelompok, maupun
\end{abstract}


komunitas, dapat tumbuh struktur dan kultur kelembagaan desa yang transparan, akuntabel, profesional, dan responsif demi mewujudkan kesejahteraan masyarakat desa yang mandiri dan berkelanjutan. Penelitian ini menyarankan, dalam jangka waktu terdekat, mempraktikkan program pemberdayaan yang mampu mengatasi isu pada jenjang individu berupa "responsibilitas personil perangkat-perangkat kelembagaan desa" karena lebih mendasar dalam hal kompleksitas isu, jumlah pemangku kepentingan, dan pendanaan. Penelitian ini memakai pendekatan kualitatif dengan studi kasus di Desa Nagarawangi, Kecamatan Rancakalong, Kabupaten Sumedang.

Kata Kunci:

kelembagaan desa, pemberdayaan desa, pembangunan desa. 


\section{PENDAHULUAN}

Situasi desa di Indonesia relatif sedang memiliki kesempatan yang banyak bisa dimanfaatkan - banyak desa digolongkan sedang "berkembang" di Indonesia. Salah satu contoh untuk mengukur kondisi desa adalah merujuk indeks potensi desa (IPD) ${ }^{1}$. Hasil pengategorian IPD menghasilkan desa tertinggal sebanyak 14.461 desa (19.17\%), desa berkembang sebanyak 55.369 desa $(73.40 \%)$, dan desa mandiri sebanyak 5.606 desa (7.43\%) (BPS, 2018). Pada 2018, semua dimensi penyusun IPD $^{2}$ mengalami peningkatan bila dibandingkan dengan 2014dimensi dengan kenaikan tertinggi adalah penyelenggaraan pemerintah desa sebesar 9.81 poin, sedangkan dimensi dengan kenaikan terkecil adalah pelayanan dasar sebesar 0,92 poin (BPS, 2018).

Meskipun demikian, tantangan yang akan dihadapi makin berat. Hal ini disebabkan oleh perubahan lingkungan akibat melalui teknologi informasi, digitalisasi, dan globalisasi. Desa kemudian dituntut agar responsif dan adaptif tanpa kehilangan nilainilai karakteristiknya. Timbul kemudian kekhawatiran besar bahwa arah implementasi UU dan sejumlah kebijakan yang akan mengubah wajah pedesaan di Indonesia jauh dari kondisi masyarakat desa yang berdaya dan terlibat dalam kemandirian mengelola sumber daya serta asetnya, menjaga kelestarian ekologi desa, melindungi tanah sebagai alat produksinya, serta mempertahankan corak produksi yang menjadi keunggulan desa (Puskapol Fisip UI, 2016).

\footnotetext{
${ }^{1}$ IPD menunjukkan tingkat perkembangan desa dengan status tertinggal, berkembang, dan mandiri

${ }^{2}$ IPD ini disusun berdasarkan lima dimensi, yaitu dimensi pelayanan dasar, dimensi kondisi infrastruktur, dimensi transportasi, dimensi pelayanan umum, dan dimensi penyelenggaraan pemerintah desa (BPS, 2018).
}

Untuk itu, beberapa penelitian menyampaikan bahwa kapasitas kelembagaan desa menjadi hal yang penting guna menghadapi situasi di atas (Nasrul, 2013; Sudjatmiko, 2014; Hargita, 2015; Muhtarom, 2016; Prasetyono et al., 2017).

Dengan demikian, berdasarkan isu yang telah diuraikan di atas, argumen penelitian ini adalah pentignnya menyusun strategi pemberdayaan kelembagaan desa guna pengembangan dan pembangunan desa. Penelitian ini kemudian akan menggunakan studi kasus di Desa Nagarawangi, Kecamatan Rancakalong, Kabupaten Sumedang. Sesuai dengan konteksnya, Desa Nagarawangi merupakan desa dengan penduduk terbanyak dan terpadat di Kecamatan Rancakalong (BPS Kab. Sumedang, 2019). Hal ini mengindikasikan bahwa ramainya sumber daya manusia di desa tersebut, sehingga mempunyai potensi untuk aktifnya organisasiorganisasi di sana. Adapun memang, berdasarkan obversasi prematur yang dilakukan untuk mengetahui kondisi lapangan pada fase awal, desa tersebut cenderung aktif organisasi-organisasi kemasyarakatannya, semisal ada PKK, DKM, Gapoktan, LPMD, kelompok olahraga dan kesenian, serta yayasan atau LSM.

\section{METODE}

Penelitian ini memakai pendekatan kualitatif dengan studi kasus di Desa Nagarawangi, Kecamatan Rancakalong, Kabupaten Sumedang. Tujuan penelitian ini adalah (1) Mendeskripsikan situasi dan kondisi kelembagaan desa di Desa Nagarawangi serta (2) Menyusun strategi pemberdayaan kelembagaan desa di Desa Nagarawangi. Proses pengumpulan data penelitian ini menggunakan wawancara 
mendalam, observasi, studi pustaka, kelembagaan-kelembagaan desa di Desa penelusuran dokumen, dan catatan lapangan. Nagarawangi, seperti pemerintah terkait, dinas Data divalidasi dengan teknik triangulasi. atau terkait, dan organisasi-organisasi desa terkait mengecek sumber lain untuk memastikan (semisal ada LPMD, PKK, DKM, Gapoktan, keselarasan data (Creswell, 2003). Lantas, data kelompok olahraga dan kesenian, serta diolah dengan teknik pengolahan tematik yayasan atau LSM, dll.). Berbagai informan berupa melakukan labeling dan coding pada tersebut diseleksi secara purposive. Artinya, data, mendeskripsikan dan mengorganisasikan pemilihannya dilakukan secara sengaja karena data berdasarkan hubungan-hubungan logis, pertimbangan konteks penelitian (Creswell, serta mengeksplorasi data berdasarkan konsep- 2003). Secara detail mengenai informan bisa konsep penelitian sebagai bagian dari proses dilihat pada Tabel 1 berikut. analisis (Creswell, 2003).

Informan utama penelitian ini dicirikan oleh pihak-pihak yang bersangkutan dengan

Tabel 1. Detail Informan

\begin{tabular}{|c|c|c|c|c|}
\hline Karakteristik & $\begin{array}{c}\text { Nama } \\
\text { (Jenis Kelamin) }\end{array}$ & Status & Alamat & Usia \\
\hline \multirow{4}{*}{$\begin{array}{c}\text { Organisasi- } \\
\text { organisasi di } \\
\text { desa (LPMD, } \\
\text { PKK, DKM, } \\
\text { Gapoktan, } \\
\text { kelompok } \\
\text { olahraga dan } \\
\text { kesenian, serta } \\
\text { yayasan atau } \\
\text { LSM, dll.) }\end{array}$} & Bapak Hamam (L) & Ketua LPMD & Dusun Cijere & 52 tahun \\
\hline & Ibu Ohay (L) & Pengurus PKK & $\begin{array}{l}\text { Dusun Pasir } \\
\text { Dokdok }\end{array}$ & 43 tahun \\
\hline & Bapak Jajang (L) & $\begin{array}{l}\text { Pengurus DKM Masjid } \\
\text { Jami' Al-Hidayah }\end{array}$ & Dusun Cijere & 47 tahun \\
\hline & Bapak Bubun (L) & $\begin{array}{c}\text { Gabungan Kelompok } \\
\text { Tani Artajaya }\end{array}$ & Dusun Cijere & 50 tahun \\
\hline \multirow[t]{2}{*}{$\begin{array}{c}\text { Pihak } \\
\text { pemerintah }\end{array}$} & Bapak Memed (L) & $\begin{array}{c}\text { Kepala Seksi } \\
\text { Kesejahteraan Rakyat } \\
\text { Desa Nagarawangi }\end{array}$ & Dusun Cijere & 59 tahun \\
\hline & $\begin{array}{c}\text { Bapak Adang } \\
\text { Sukmansyah (L) }\end{array}$ & $\begin{array}{c}\text { Ketua BPD Desa } \\
\text { Nagarawangi }\end{array}$ & $\begin{array}{l}\text { Dusun Pasir } \\
\text { Benteng }\end{array}$ & 46 tahun \\
\hline
\end{tabular}

Sumber: diolah mandiri

\section{HASIL PENELITIAN}

Hasil penelitian pada bab ini akan dibagi menjadi dua subbab, yaitu Sekilas tentang Desa Nagarawangi dan Kelembagaan Desa Nagarawangi. Untuk subbab pertama, Sekilas tentang Desa Nagarawangi, akan memuat soal gambaran umum desa tersebut secara monografi. Kemudian, yang kedua, Kelembagaan Desa Nagarawangi, akan berisi tentang kondisi-kondisi nyata kelembagaan yang ada di desa tersebut - sesuai dengan topik yang ditawarkan penelitian ini.

\section{Sekilas tentang Desa Nagarawangi ${ }^{3}$}

$\begin{array}{rrr}\text { Desa } & \text { Nagarawangi } & \text { terletak di } \\ \text { Kecamatan } & \text { Rancakalong, } & \text { Kabupaten }\end{array}$

${ }^{3}$ Seluruh data di subbab ini diolah dari sumber BPS Kab. Sumedang 2016, 2016b, 2017, 2018, 2018b, dan 2019 serta Monografi Desa Nagarawangi 2018. Seluruh data tersebut adalah data terkini yang tersedia di BPS Kab. Sumedang dan yang diserahkan kepada peneliti oleh Pihak Pemerintah Desa Nagarawangi 
Sumedang, Jawa Barat, Indonesia. Desa Nagarawangi mempunyai luas Wilayah 463 Ha, terletak di Ibu Kota Kecamatan Rancakalong dan merupakan Pusat Pemerintahan wilayah kecamatan Rancakalong dengan jarak tempuh \pm 0.300 $\mathrm{Km}$. Desa ini berada di pinggir jalan provinsi yang merupakan akses jalan SumedangRancakalong-Tanjungsari. Wilayah Desa Nagarawangi merupakan perbukitan dan persawahan dengan ketinggian $600-700 \mathrm{~m}$ di atas permukaan laut dengan suhu udara $25^{\circ} \mathrm{C}$.

Secara administratif, Desa Nagarawangi terbagi ke dalam sembilan wilayah Rukun Warga (RW) dan 37 wilayah Rukun Tetangga (RT). Desa Nagarawangi, pada 2018, merupakan desa dengan penduduk terbanyak dan terpadat di Kecamatan Rancakalong, sehingga warganya aktif dalam organisasiorganisasi desa. Total jumlah penduduknya adalah 5459 jiwa dengan laki-laki 2937 jiwa dan perempuan 2522 jiwa. Sementara itu, kepadatannya adalah 1272 Jiwa/ $/ \mathrm{Km}^{2}$. Sebagian besar penduduk Desa Nagarawangi bekerja di sektor perdagangan dan sektor pertanian baik sebagai petani maupun buruh tani. Sebagian kecil lainnya bekerja di sektor transportasi dan jasa.

\section{Kelembagaan Desa Nagarawangi}

Menurut UU 6/2014 tentang Desa, disebutkan bahwa kelembagaan desa itu meliputi:

(a) Pemerintahan Desa atau Desa Adat yang terdiri atas Pemerintah Desa atau Pemerintah Desa Adat dan Badan Permusyawaratan Desa atau Badan Permusyawaratan Desa Adat

(b) Lembaga Kemasyarakatan Desa

(c) Lembaga adat
Fungsi dari Pemerintah Desa atau Desa Adat adalah penyelenggaraan urusan pemerintahan dan kepentingan masyarakat setempat dalam sistem pemerintahan Negara Kesatuan Republik Indonesia; kemudian, fungsi dari Lembaga Kemasyarakatan Desa adalah sebagai wadah partisipasi masyarakat Desa dalam pembangunan, pemerintahan, kemasyarakatan, dan pemberdayaan yang mengarah terwujudnya demokratisasi dan transparansi di tingkat masyarakat serta menciptakan akses agar masyarakat lebih berperan aktif dalam kegiatan pembangunan; terakhir, fungsi dari Lembaga Adat adalah membantu Pemerintah Desa dan sebagai mitra dalam memberdayakan, melestarikan, dan mengembangkan adat istiadat sebagai wujud pengakuan terhadap adat istiadat masyarakat Desa.

Dalam konteks di Desa Nagarawangi, lembaga-lembaga desa yang ada dan berfungsi di desa tersebut adalah pemerintah desa dan lembaga kemasyarakatan desa. Dalam penelitian ini, khususnya melalui subbab ini, akan dibahas mengenai pemerintahan desa yang meliputi pemerintah Desa Nagarawangi secara umum dan BPD. Keduanya tentu sangat berperan dalam pengembangan dan pembangunan Desa Nagarawangi. Kemudian, untuk lembaga kemasyarakatan Desa Nagarawangi, lembaga-lembaga yang akan dibahas adalah LPMD, PKK, DKM, dan Gapoktan.

Pertama, Pemerintah Desa Nagarawangi mempunyai visi bagi desanya berupa "terwujudnya desa nagarawangi sebagai desa yang sejahtera rancage aman sauyunan dan iman yang didukung oleh masyarakat yang bertakwa kepada Tuhan yang Maha Esa". Visi tersebut kemudian tergambarkan pada moto desa yang 
menggunakan bahasa asli daerahnya, bahasa Sunda, yaitu "serasi nagarawangi sejahtera rancage aman sauyunan dan iman". Dalam Rencana Pembangunan Jangka Menengah Desa Nagarawangi pada 2017, disebutkan ada beberapa misi yang diupayakan untuk memenuhi visi dan moto dari desa tersebut (Desa Nagarawangi, 2018):

(a) Peningkatan daya beli masyarakat untuk meningkatkan kesejahteraan masyarakat desa untuk kemiskinan

(b) Meningkatkan kegiatan masyarakat untuk mencapai sumber daya yang berkualitas masyarakat desa melauli bidang pertanian, peternakan, dan agrobisnis

(c) Meningkatkan kesadaran masyarakat desa dalam bidang keamanan, ketertiban baik secara umum maupun masyarakat itu sendiri yang berkualitas

(d) Meningkatkan kembali kegiatan gotongroyong masyarakat yang produktif, kreatif, dan inovatif yang difasilitasi pemerintah desa

(e) Meningkatkan keimanan masyarakat yang didukung dengan ketakwaan kepada Tuhan yang Maha Esa

Salah satu upaya praktis yang dilakukan oleh Pemerintah Desa Nagarawangi untuk pembangunan daerah dan warganya adalah melakukan mekanisme program pelatihan dan pemberdayaan. Program tersebut umumnya selalu dilakukan baik oleh pemerintah desa sendiri, dukungan pemerintah daerah dan pusat, swasta, maupun organisasi-organisasi masyarakat. Periode waktunya bermacammacam, ada yang bersifat mingguan, periodik atau insidentil (menyesuaikan dengan kebutuhan dan selama adanya kerja sama dengan pihak lain), bahkan tahunan dan secara berkelanjutan. Berikut beberapa program pelatihan, pemantauan dan evaluasi, serta pemberdayaan yang dilakukan di Desa Nagarawangi bagi penduduknya-baik anggota kelembagaan maupun warganya secara umum (berdasarkan wawancara mendalam dengan Bapak Memed, Kepala Seksi Kesejahteraan Desa Nagarawangi):

(a) Acara mingguan desa: pembinaan kelembagaan desa, rapat koordinasi desa, dan rapat evaluasi lembaga-lembaga desa

(b) Pembinaan sewaktu-waktu tergantung kebutuhan (pembinaan insidentil):

(c) Adanya pelatihan-pelatihan dari luar (kecamatan, kabupaten, dinas terkait) bagi anggota kelembagaan desa

(d) Monitoring dan evaluasi lembaga oleh pihak desa, kecamatan, kabupaten dan dinas terkait

Kedua, Badan Permusyawaratan Desa (BPD) Desa Nagarawangi ialah salah satu badan yang penting dan cukup berperan dalam kelembagaan untuk memengaruhi pembangunan dan pemberdayaan desa. Adapun dalam kesehariannya, BPD Desa Nagarawangi mempunyai tugas, pokok, dan fungsi (tupoksi) - menyangkut upaya praktis dalam mewujudkan fungsi umum yang tercantum dalam undang-undang-sebagai berikut (berdasarkan wawancara mendalam dengan Bapak Adang Sukmansyah, Ketua BPD Desa Nagarawangi):

(a) Menggali, menampung, dan mengelola aspirasi masyarakat

(b) Menyatukan masyarakat

(c) Menyelenggarakan musyawarah BPD

(d) Membentuk panitia pemilihan kades

(e) Menyelenggarakan musyawarah desa

(f) Membahas dan menyepakati rancangan peraturan desa antar waktu

(g) Melaksanakan pengawasan kinerja kades

(h) Melakukan evaluasi soal penyelenggaraan Pemerintahan Desa 
(i) Menciptakan hubungan kerja harmonis dengan Pemerintahan Desa dan Lembaga Desa lainnya dan memaksimalkan tugas lain yang diatur dalam ketentuan peraturan perundang-undangan No. 110/2016

Ketiga, sebagai bagian dari Lembaga Kemasyarakatan Desa, Lembaga Pemberdayaan Masyarakat Desa (LPMD) Nagarawangi merupakan lembaga atau wadah yang dibentuk atas prakarsa masyarakat sebagai mitra pemerintah desa dan lurah dalam menampung dan mewujudkan aspirasi serta kebutuhan masyarakat di bidang pembangunan. Di Desa Nagarawangi, LPMD pun dibentuk agar pemerintah memiliki mitra dalam mewujudkan pembangunan yang partisipatif bagi warganya. peran atau kewenangan LPMD di Desa Nagarawangi adalah sebagai berikut (berdasarkan wawancara mendalam dengan Bapak Hamam, Ketua LPMD Desa Nagarawangi):

(a) Menyusun rencana pembanungan secara pastisipatif

(b) Menggerakkan swadaya gotong-royong masyarakat

(c) Melaksanakan dan juga mengendalikan pembangunan

Kemudian, fungsi dari LPMD di Desa Nagarawangi adalah sebagai berikut (berdasarkan wawancara mendalam dengan Bapak Hamam, Ketua LPMD Desa Nagarawangi):

(a) Penampung dan penyalur soal aspirasi masyarakat desa dalam pembangunan

(b) Peningkat kualitas pelayanan pemerintah kepada masyarakat

(c) Penyusun rencana, pelaksana, pengendali, pelestari, dan pengembang hasil-hasi dari pembangunan desa secara partisipatif (d) Penumbuh-kembang dan penggerak dari partisipasi masyarakat serta swadaya gotong-royong masyarakat

(e) Penggali, pendayaguna, dan pengembang potensi sumber daya serta keserasian lingkungan hidup di desa

Keempat, sebagai bagian dari Lembaga

Kemasyarakatan Desa, Pembinaan Kesejahteraan Keluarga (PKK) Desa Nagarawangi adalah lembaga kemasyarakatan yang berposisi sebagai mitra kerja pemerintah dan organisasi kemasyarakatan lainnya dan berfungsi sebagai fasilitator, perencana, pelaksana, pengendali, dan penggerak pada masing-masing jenjang pemerintahan untuk terlaksananya program-program kesejahteraan keluarga atau peran-peran perempuan. Di Desa Nagarawangi, beberapa peran programprogram pemberdayaan yang dilaksanakan dan dijalankan secara berkelanjutan oleh PKK adalah sebagai berikut (berdasarkan wawancara mendalam dengan Ibu Ohay, Pengurus PKK Desa Nagarawangi):

(a) Pokja 1: pengajian rutin 1 minggu sekali tiap RT dan 1 bulan sekali tiap RW

(b) Pokja 2: upaya peningkatan pendapatan keluarga melalui simpan pinjam dan usaha produktif

(c) Pokja 3: pemanfaatan pekarangan guna penghasilan keluarga

(d) Pokja 4: pertemuan rutin arisan dan pembinaan, kegiatan di posyandu dalam satu bulan sekali dengan jumlah delapan posyandu, serta pertemuan kader sebanyak 46 orang dalam satu bulan sekali)

Kelima, sebagai bagian dari Lembaga Kemasyarakatan Desa, Dewan Kemakmuran Masjid (DKM) di Desa Nagarawangi mempunyai peran penting mengingat warga di Desa Nagarawangi mayoritas beragama Islam. Beberapa peran khusus yang dimiliki oleh 
DKM di Desa Nagarawangi guna mewjudukan misi tersebut adalah sebagai berikut (berdasarkan wawancara mendalam dengan Bapak Jajang, Pengurus DKM Masjid Jami' Al-Hidayah, Desa Nagarawangi):

(a) Meningkatkan kesejahteraan rohani umat

(b) Memberikan kenyamanan kepada jama'ah dalam beribadah di masjid

(c) Mengelola dan mendata kas masjid untuk kesejahteraan umat

(d) Mengelola sarana-prasarana masjid

Adapun kegiatan-kegiatannya yang lebih spesifik dan mendetail bagi DKM di Desa Nagarawangi adalah sebagai berikut (berdasarkan wawancara mendalam dengan Bapak Jajang, Pengurus DKM Masjid Jami' Al-Hidayah, Desa Nagarawangi):

(a) Menyelenggarakan ibadah-ibadah agama Islam seperti salat, pengajian, dll.

(b) Memfasilitasi kegiatan-kegiatan peringatan hari besar Islam

(c) Mengadakan pendidikan, pelatihan, dan pemberdayaan agama Islam untuk jama'ah

Terakhir, keenam, sebagai bagian dari Lembaga Kemasyarakatan Desa, Gabungan Kelompok Tani (Gapoktan) Artajaya adalah kumpulan beberapa kelompok tani yang bergabung dan bekerja sama untuk meningkatkan skala ekonomi dan efisiensi usaha di Desa Nagarawangi. Peran dari Gapoktan di Desa Nagarawangi sangatlah signifikan sebab sebagian besar penduduk Desa Nagarawangi bekerja di sektor pertanian baik sebagai petani maupun buruh tani. Khusus bagi Gapoktan Artajaya, yang merupakan Gapoktan yang berada di Desa Nagarawangi, beberapa program yang dijalankan adalah sebagai berikut (berdasarkan wawancara mendalam dengan Bapak Bubun, Pengurus Gabungan Kelompok Tani Artajaya, Desa Nagarawangi): (a) Pemberdayaan anggota tani, pelatihan dalam rentang sebulan sekali. Adapun bentuknya seperti pemberdayaan pertanian dengan jenis padi, jagung, ubi, swasembada pangan, dan pemberdayaan persoalan-persoalan pertanian seperti saluran irigasi, pemburuan hama tikus, wereng, dan pupuk

(b) Pertemuan anggota rutin dengan jumlah yang aktif kurang lebih dua lima orang

(c) Pemberian bantuan-bantuan teknis dan nonteknis. "Kalau ada bantuan teknis, kayak diberi pupuk, cangkul, dll, semua anggota cenderung datang," ujar Bapak Bubun

(d) Melakukan relasi dengan desa, dinas, swasta, dan sebagainya.

\section{PEMBAHASAN}

Pada bab ini, akan dipaparkan soal analisis atas kondisi kelembagaan di Desa Nagarawangi, Kecamatan Rancakalong, Kabupaten Sumedang. Namun, sebelum untuk memulai analisis yang berupa strategi pemberdayaan kelembagaan, akan dijelaskan dulu soal kendala-kendala kelembagaan yang ada di Desa Nagarawangi. Kendala-kendala tersebut nanti akan mencakup seluruh jenis kelembagaan, baik itu berupa Pemerintahan Desa maupun Kelembagaan Kemasyarakatan Desa. Analisis berupa strategi pemberdayaan kelembagaan selaras dengan argumen penelitian ini, yaitu pentignnya menyusun strategi pemberdayaan kelembagaan desa guna pengembangan dan pembangunan desa.

\section{Kendala Kelembagaan Desa Nagarawangi}

Dengan diterbitkannya UU 6/2014 tentang Desa serta PP 8/2016 (Perubahan Kedua PP 6/2014) tentang Dana Desa, desa memiliki kewenanganan otonomi (local-self 
government) dalam dua aspek berikut (Wicaksono, 2016):

(a) Kebutuhan dasar masyarakat seperti air, kesehatan, pendidikan, lingkungan, dan keamanan

(b) Kebutuhan pengembangan usaha bagi masyarakat seperti pertanian, perkebunan, perdagangan, industri, dan sebagainya

Dalam menjalankan tanggung jawabnya tersebut, pemerintah desa diharapkan memiliki kapasitas dalam menjalankan fungsi administratif dan manajerial birokrasi serta kelembagaan yang kuat, transparan, akuntabel, dan responsif (Wicaksono, 2016).

Namun, dalam penelitian ini yang melakukan riset lapangan di Desa Nagarawangi, Kecamatan Rancakalong, Kabupaten Sumedang ditemukan bahwa ada beberapa kendala yang memang menjadi penghalang bagi desa tersebut untuk memenuhi "makna otonomi"-nya dan menciptakan kapasitas dalam menjalankan fungsi administratif dan manajerial birokrasi serta kelembagaan yang kuat, transparan, akuntabel, dan responsif. Kendala-kendala itu setidaknya dapat dilihat sebagai berikut:

(a) Kendala bagi Pemerintah Desa (berdasarkan wawancara mendalam dengan Bapak Memed, Kepala Seksi Kesejahteraan Desa Nagarawangi):

- Kehadiran anggota kadang tidak memenuhi sesuai undangan (karena cuaca, kesibukan kerja, dll.)

(b) Kendala bagi BPD (berdasarkan wawancara mendalam dengan Bapak Adang Sukmansyah, Ketua BPD Desa Nagarawangi):

- Kendala mengenai persoalan organisasi:

- Berkaitan dengan struktur dan tanggung jawab terkadang terabaikan karena kepentingan individu dan ini tidak dapat dihindari karena kepentingan tersebut hal yang sangat penting serta mendesak terutama untuk keluarga atau profesi

- Berkaitan dengan dana organisasi. Tidak ada anggaran khusus untuk kegiatan organisasi, yang ada hanya anggaran bulanan untuk masyarakat

- Kendala yang dihadapi mengenai relasi dengan pemerintah desa terkadang ada salah paham dalam hal terntentu, namun selalu ada solusi dengan duduk bersama dalam hal akuntabilitas maupun transparansi penyelenggaraan pemerintah baik pembangunan fisik dan nonfisik ataupun pertanggung-jawaban keuangan

- Kendapa yang dihadapi mengenai pengelolaan anggota atau SDM:

- Kompensasi masing-masing anggota yang berbeda yang bisa menentukan jarak langkah orang, baik dari latar pendidikan maupun karakter masing-masing

- Kepentingan pribadi yang mewakili wilayah ada masingmasing, terkadang membuat tingginya ego dan perbedaan visi/misi

(c) Kendala bagi LPMD (berdasarkan wawancara mendalam dengan Bapak Hamam, Ketua LPMD Desa Nagarawangi):

- Kurang tahunya masyarakat tentang kegiatan yang diadakan LPM

- Banyak masyarakat yang tidak peduli/tidak mau partisipasi dalam 
kegiatan yang dilakukan LPM

- Kurangnya dana yang dipergunakan untuk pembangunan sehingga menyebabkan pembangunan di desa berjalan dengan lambat

- Kurangnya pembinaan mengenai kegiatan LPM

- Kurangnya kekompakan antar pengurus LPM

- Kurangnya komunikasi antar lembaga desa yang ada di pemerintahan desa

- Kurangnya rasa tanggung-jawab terhadap tupoksi masing-masing

(d) Kendala bagi PKK (berdasarkan wawancara mendalam dengan Ibu Ohay, Pengurus PKK Desa Nagarawangi):

- Dana. Tidak ada dana khusus untuk kegiatan PKK dari desa, hanya pelatihan-pelatihan, pembinaan saja

- Dana diambil dari UP2K

- Anggota/SDM: dalam pertemuan masih ada beberapa anggota yang tidak hadir, yang aktif hanya itu-itu saja (sibuk mengurus anak, bekerja, jualan, dll.)

(e) Kendala bagi Gapoktan (berdasarkan wawancara mendalam dengan Bapak Bubun, Pengurus Gabungan Kelompok Tani Artajaya, Desa Nagarawangi):

- Dana untuk pupuk dan lain-lain (Dinas Pertanian) tidak turun secara periodik atau rutin

- Dana dari desa tidak turun secara periodik atau rutin

- Kesempatan yang diberikan desa menyangkut akses pasar kurang

Dari beragam kendala kelembagaan yang disebutkan di atas, maka, dapat dikategorisasikan bahwa ada tiga aspek besar menyangkut tantangan kelembagaan yang terjadi di Desa Nagarawangi, yaitu: (a) Tantangan aspek tata laksana SDM

(b) Tatangan aspek tata laksana organisasional

(c) Tantangan aspek pengawasan

Pertama, aspek tata laksana SDM merupakan tantangan dalam hal penerapan organisasional yang mumpuni akibat adanya persoalan aspek sumber daya manusia yang dimiliki (Djaha, 2006; 2007). Artinya, tantangan ini mencakup kapasitas perangkatperangkat kelembagaan desa dalam manajemen, keuangan, administrasi, pelayanan publik, dan teknis lainnya. Khusus bagi Desa Nagarawangi, tantangan aspek tata laksana SDM yang ada berdasarkan kendalakendala di atas mencakup:

(a) Responsibilitas personil perangkatperangkat kelembagaan desa

(b) Kemampuan inovatif perangkat-perangkat kelembagaan desa perihal pemerintahan dan pelayanan pembangunan desa

(c) Kemampuan pengelolaan keuangan

Kedua, aspek tata laksana organisasional merupakan tantangan penerapan tata kelola pemerintahan yang efektif, efisien, handal, transparan, dan akuntabel (Djaha, 2006; 2007). Hal-hal di sini terkait seperti dengan kapabilitas manajemen organisasional, penyusunan peraturan desa, pengelolaan dana desa, perencanaan partisipatif, pemberdayaan masyarakat, dan sebagainya. Khusus bagi Desa Nagarawangi, tantangan aspek tata laksana organisasional yang ada berdasarkan kendala-kendala di atas mencakup:

(a) Konsolidasi internal kelembagaan

(b) Daya tanggap kelembagaan terhadap kebutuhan masyarakat

Ketiga, terakhir, aspek pengawasan merupakan tantangan yang timbul akibat lemahnya mekanisme pengawasan dan dapat menjadi potensi korupsi, penyalahgunaan 
wewenang, dan penyalahgunaan diskresi (Djaha, 2006; 2007). Artinya, ini perlu penguatan pengawasan dalam hal-hal seperti pemantauan keuangan, saluran pengaduan masyarakat yang efektif, mudah dan murah, serta respon terhadap pengaduan masyarakat desa. Khusus bagi Desa Nagarawangi, tantangan aspek tata laksana organisasional yang ada berdasarkan kendala-kendala di atas mencakup:

(a) Pemantauan keuangan atau aliran dana

(b) Saluran pengaduan masyarakat desa yang efektif

Tabel 5. Ringkasan Kendala Kelembagaan Desa Nagarawangi

\begin{tabular}{|c|c|c|c|}
\hline $\begin{array}{c}\text { Kendala Kelembagaan Desa } \\
\text { Nagarawangi } \\
\text { (Hasil Temuan Lapangan) }\end{array}$ & $\begin{array}{l}\text { Dampak Kendala: } \\
\text { Timbulnya Tantangan }\end{array}$ & $\begin{array}{c}\text { Aspek-aspek } \\
\text { Tantangan }\end{array}$ & $\begin{array}{c}\text { Efeknya Jika } \\
\text { Tantangan Tidak } \\
\text { Diselesaikan }\end{array}$ \\
\hline $\begin{array}{l}\text { - } \begin{array}{l}\text { Anggota masih banyak yang tidak hadir } \\
\text { dalam pertemuan }\end{array} \\
\text { - Kepentingan pribadi anggota kerap } \\
\text { diutamakan } \\
\text { - Anggota kurang bertanggung jawab } \\
\text { atas tupoksi }\end{array}$ & $\begin{array}{l}\text { Responsibilitas personil } \\
\text { perangkat-perangkat } \\
\text { kelembagaan desa }\end{array}$ & \multirow[t]{3}{*}{$\begin{array}{l}\text { Aspek tata } \\
\text { laksana SDM }\end{array}$} & \multirow{3}{*}{$\begin{array}{c}\text { Kinerja } \\
\text { kelembagaan desa } \\
\text { menjadi terhambat } \\
\text { dalam } \\
\text { mewujudkan } \\
\text { pengembangan } \\
\text { dan pembangunan } \\
\text { desa secara } \\
\text { mandiri dan } \\
\text { berkelanjutan }\end{array}$} \\
\hline $\begin{array}{l}\text { Masyarakat desa banyak tidak ikut } \\
\text { kegiatan pemberdayaan } \\
\text { Masyarakat desa tidak datang ke } \\
\text { beberapa kegiatan pemberdayaan }\end{array}$ & $\begin{array}{l}\text { Kemampuan inovatif perangkat- } \\
\text { perangkat kelembagaan desa } \\
\text { perihal pemerintahan dan } \\
\text { pelayanan pembangunan desa }\end{array}$ & & \\
\hline $\begin{array}{l}\text { - } \begin{array}{l}\text { Dana bantuan tidak lancar dan tidak } \\
\text { rutin } \\
\text { - } \\
\text { Kekurangan anggaran untuk } \\
\text { mengadakan kegiatan-kegiatan } \\
\text { pemberdayaan }\end{array} \\
\end{array}$ & $\begin{array}{c}\text { Kemampuan pengelolaan } \\
\text { keuangan }\end{array}$ & & \\
\hline $\begin{array}{l}\text { Komunikasi terhambat antar lembaga } \\
\text { dan kepada pemerintah yang levelnya } \\
\text { lebih tinggi (daerah atau pusat, dinas } \\
\text { atau kementerian) } \\
\text { Kurangnya kekompakan antar pengurus } \\
\text { lembaga }\end{array}$ & $\begin{array}{l}\text { Konsolidasi internal } \\
\text { kelembagaan }\end{array}$ & \multirow[t]{2}{*}{$\begin{array}{c}\text { Aspek tata } \\
\text { laksana } \\
\text { organisasional }\end{array}$} & \multirow[t]{2}{*}{$\begin{array}{c}\text { Tidak } \\
\text { terwujudnya } \\
\text { kinerja } \\
\text { kelembagaan desa } \\
\text { yang profesional } \\
\text { dan responsif }\end{array}$} \\
\hline $\begin{array}{l}\text { Kurangnya akses pasar bagi produk } \\
\text { pertanian petani } \\
\text { - Kurangnya pembinaan bagi pelaksana } \\
\text { teknis pemberdayaan }\end{array}$ & $\begin{array}{l}\text { Daya tanggap kelembagaan } \\
\text { terhadap kebutuhan masyarakat }\end{array}$ & & \\
\hline $\begin{array}{l}\text { Dana bantuan tidak lancar dan tidak } \\
\text { rutin } \\
\text { Kekurangan anggaran untuk } \\
\text { mengadakan kegiatan-kegiatan } \\
\text { pemberdayaan }\end{array}$ & $\begin{array}{l}\text { Pemantauan keuangan atau } \\
\text { aliran dana }\end{array}$ & \multirow[t]{2}{*}{$\begin{array}{c}\text { Aspek } \\
\text { pengawasan }\end{array}$} & \multirow[t]{2}{*}{$\begin{array}{l}\text { Tidak } \\
\text { terwujudnya } \\
\text { kinerja } \\
\text { kelembagaan desa } \\
\text { yang transparan } \\
\text { dan akuntabel }\end{array}$} \\
\hline $\begin{array}{l}\text { Beberapa aspirasi masyarakat desa } \\
\text { tidak terserap }\end{array}$ & $\begin{array}{c}\text { Saluran pengaduan masyarakat } \\
\text { desa yang efektif }\end{array}$ & & \\
\hline
\end{tabular}

Sumber: diolah mandiri 
Strategi Pemberdayaan Kelembagaan Desa Tiga Jenjang

Strategi pemberdayaan kelembagaan desa yang ditawarkan penelitian ini mengacu pada definisi konsep pemberdayaan Zimmerman (2010). Menurutnya, ide pemberdayaan memiliki dua kecenderungan, antara lain (Zimmerman, 2010): (1) kecenderungan primer: kecenderungan proses yang memberikan atau mengalihkan sebagian kekuasaan, kekuatan, atau kemampuan (power) kepada masyarakat atau individu agar menjadi lebih berdaya. Proses ini dapat dilengkapi pula dengan upaya membangun aset material guna mendukung pembangunan kemandirian mereka melalui organisasi dan kelembagaan serta (2) kecenderungan sekunder: kecenderungan yang menekankan pada proses memberikan stimulasi, mendorong, atau memotivasi individu agar mempunyai kemampuan atau keberdayaan untuk menentukan apa yang menjadi pilihan hidupnya melalui proses dialog.

Dari pernyataan tersebut, praktik pemberdayaan masyarakat desa diarahkan untuk memberikan jaminan masyarakat desa mampu mengelola secara mandiri perencanaan, pelaksanaan, pengawasan, dan evaluasi kegiatan pembangunan desa beserta pendayagunaan hasil-hasil pembangunan desa yang semuanya itu dilakukan secara mandiri. Pengembangan kapasitas ini beberapa contohnya kemudian bisa dilakukan melalui penyediaan tenaga pendamping dan pelatihanpelatihan secara berkelanjutan.

Pada Tabel 5 di atas terlihat bahwa ada tiga aspek penting yang menjadi tantangan bagi kelembagaan Desa Nagarawangi, yaitu aspek tata laksana SDM, aspek tata laksana organisasional, dan aspek pengawasan. Ketiga hal tersebut perlu diselesaikan agar tidak berujung pada efek masing-masingnya yang menghambat proses pembangunan desa. Tantangan pada aspek tata laksana SDM akan berujung pada kinerja kelembagaan desa yang menjadi terhambat dalam mewujudkan pengembangan dan pembangunan desa secara mandiri dan berkelanjutan. Kemudian, tantangan pada aspek tata laksana organisasional akan berujung pada tidak terwujudnya kinerja kelembagaan desa yang profesional dan responsif. Terakhir, tantangan pada aspek pengawasan akan berujung pada tidak terwujudnya kinerja kelembagaan desa yang transparan dan akuntabel.

Oleh sebab hal di atas, tiga tantangan menyangkut aspek kelembagaan di Desa Nagarawangi memiliki level analisisnya yang berbeda-beda. Dalam arti, secara lebih jelas, tantangan pada aspek tata laksana SDM berada di level individual, sehingga membutuhkan mekanisme pemberdayaan dengan sasaran berupa individu atau mekanisme pemberdayaan dengan sasaran peningkatan kapabilitas perangkat-perangkat kelembagaan desa. Selanjutnya, tantangan pada aspek tata laksana organisasional berada di level meso atau kelompok, sehingga membutuhkan mekanisme pemberdayaan dengan sasaran berupa setiap lembaga desa atau mekanisme pemberdayaan dengan sasaran perbaikan sistem dan tata kelola lembaga atau organisasi secara internal. Terakhir, tantangan pada aspek pengawasan berada di level komunitas, sehingga membutuhkan mekanisme pemberdayaan dengan sasaran berupa setiap lembaga desa beserta kemampuannya dalam berjejaring atau mekanisme pemberdayaan dengan sasaran optimalisasi kinerja lembaga atau organisasi secara internal maupun eksternal dalam menjaring mitra. Alhasil, dengan menyentuh 


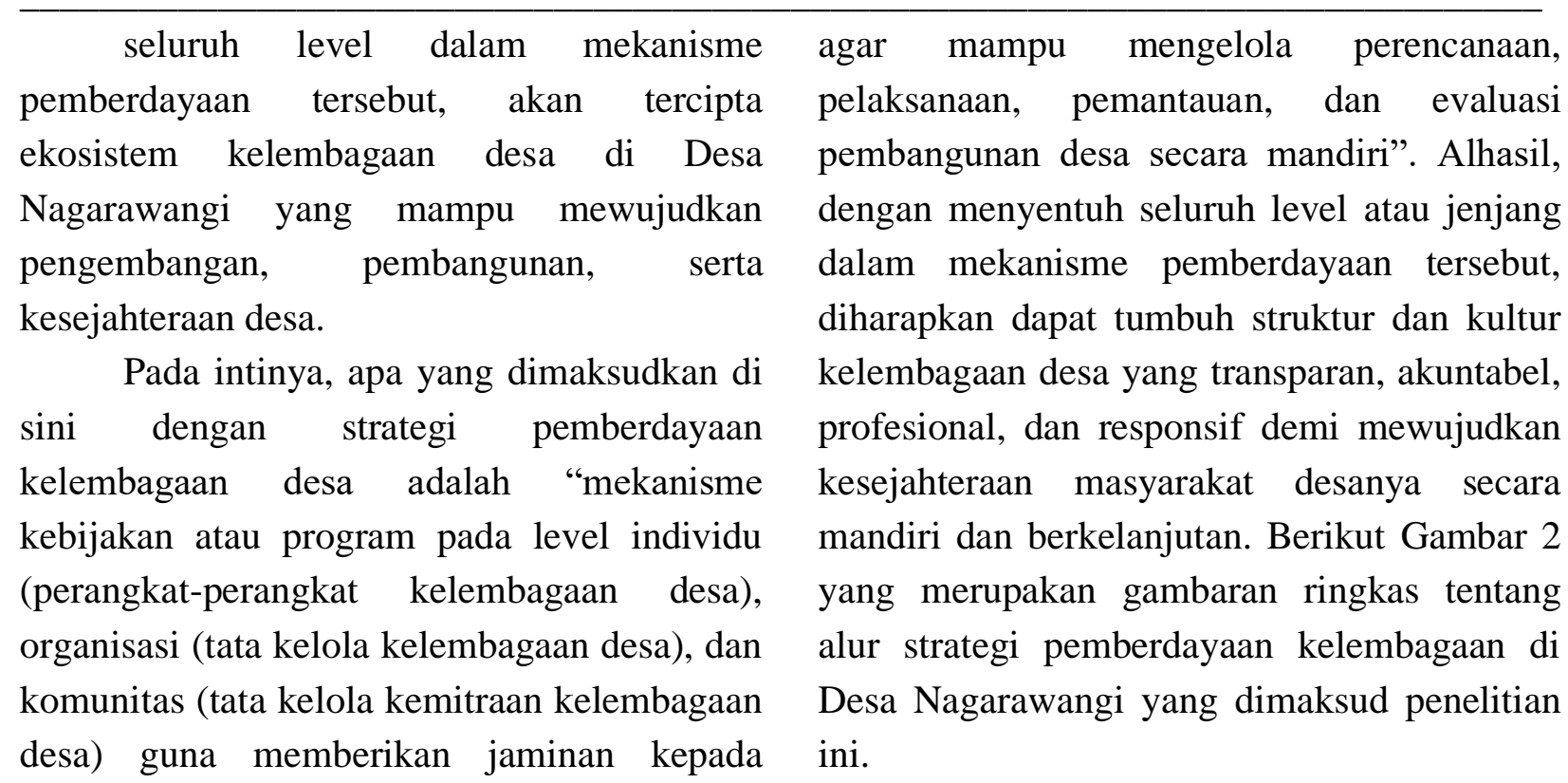

lembaga-lembaga ataupun masyarakat desa 
LINDAYASOS: Jurnal Ilmiah Perlindungan dan Pemberdayaan Vol. 2 No. 1, Juni 2020

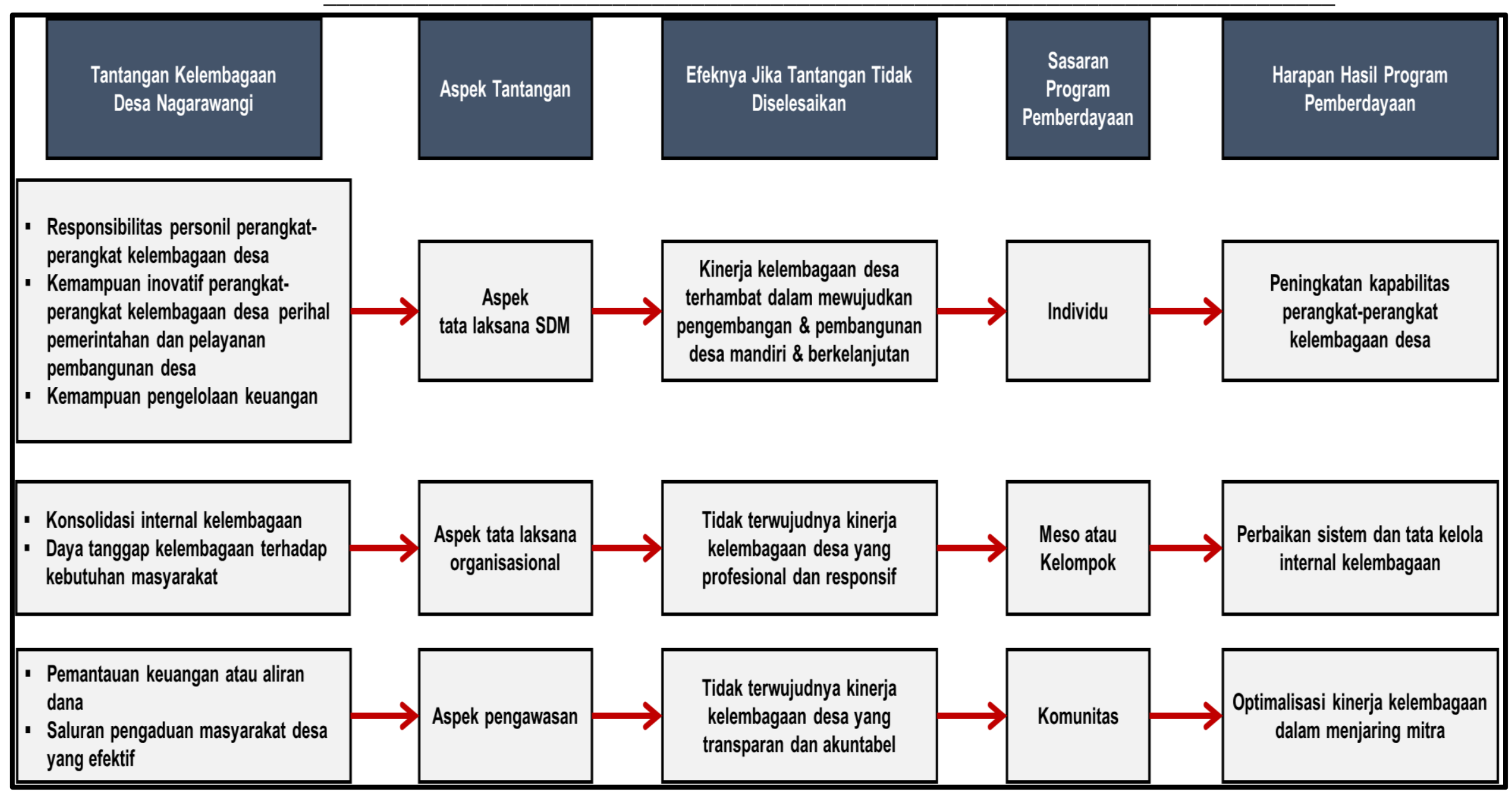

Gambar 2. Alur Strategi Pemberdayaan Kelembagaan Tiga Jenjang Bagi Kelembagaan di Desa Nagarawangi

Sumber: diolah mandiri 
Dari alur yang tampak pada Gambar 2 di atas, dapat dilihat bahwa ada strategi pemberdayaan kelembagaan yang dilakukan pada tiga jenjang yang berbeda, yaitu pada jenjang individu, meso atau kelompok, dan komunitas.

Hal mendasar yang menjadi masalah dalam tantangan kelembagaan ini dan perlu diselesaikan segera dalam jangka waktu dekat ialah "responsibilitas personil perangkatperangkat kelembagaan desa". Hal ini tentu perlu diselesaikan dengan skema pemberdayaan di level individu, tepatnya bertemakan "peningkatan kapabilitas perangkat-perangkat kelembagaan desa". Beberapa bentuk programnya dapat berupa "pelatihan dan evaluasi reguler kepada pengurus pemerintah desa, BPD, dan lembaga kemasyarakatan desa tentang" 'etika dan moral pelayan publik' serta 'bimbingan dan pendampingan teknis kepada pengurus pemerintah desa dalam 'menyusun dan menerapkan sistem pengawasan kegiatan dan evaluasi kinerja aparat kelembagaan desa"”.

Berikutnya, hal yang perlu diselesaikan dalam jangka waktu menengah dan ini ada pada level meso atau kelompok adalah "perbaikan sistem dan tata kelola internal kelembagaan". Ini penting untuk kelembagaan desa dalam mengatasi persoalan-persoalan kontemporer. Beberapa bentuk program pemberdayaannya seperti "bimbingan dan pendampingan teknis kepada seluruh kelembagaan di desa untuk 'mereformasi metode dan sistem saluran komunikasi internal dan eksternal" serta "pelatihan reguler kepada seluruh kelembagaan di desa tentang 'pendataan dan asesmen potensi lokal dan cost benefit analysis"".

Terakhir, dalam jangka panjang karena melibatkan banyak pihak, ini ada pada aspek pengawasan dengan level komunitas. Ini untuk mengatasi isu "pemantauan keuangan atau aliran dana". Beberapa bentuk program pemberdayaannya dapat seperti "mengadakan program kerja sama dengan swasta atau komunitas teknologi atau generasi muda dalam pemanfaatan teknologi, informasi, dan komunikasi di kabupaten dan desa untuk sistem pengawasan dan penyaluran alokasi dana", "bekerja sama dengan KPK untuk mempromosikan tindakan pencegahan korupsi di kabupaten dan desa", "mengadakan pelatihan media tentang dana desa di desadesa untuk transparansi dan akuntabilitas", "menyelenggarakan forum nasional dan regional tentang praktik terbaik, keberhasilan, dan tantangan penyaluran dan alokasi dana desa di antara para pemangku kepentingan", dan lain-lain. Adapun secara lebih spesifik, berikut tabel yang memuat program-program pemberdayaan yang ditawarkan oleh penelitian ini beserta sasaran pencapaian indikatornya demi mengatasi tantangantantangan kelembagaan di Desa Nagarawangi: 
LINDAYASOS: Jurnal Ilmiah Perlindungan dan Pemberdayaan Vol. 2 No. 1, Juni 2020

Tabel 6. Bentuk-bentuk Tawaran Program Pemberdayaan bagi Kelembagaan Desa di Desa Nagarawangi

Sumber: diolah mandiri

\begin{tabular}{|c|c|c|c|c|c|c|}
\hline $\begin{array}{l}\text { Tantangan Kelembagaan } \\
\text { Desa Nagarawangi }\end{array}$ & $\begin{array}{c}\text { Sasaran } \\
\text { Program } \\
\text { Pemberdayaan } \\
\end{array}$ & & $\begin{array}{c}\text { Bentuk-bentuk Tawaran Program } \\
\text { Pemberdayaan }\end{array}$ & & $\begin{array}{l}\text { Sasaran Indikator Keberhasilan } \\
\text { Program Pemberdayaan }\end{array}$ & $\begin{array}{l}\text { Harapan Hasil } \\
\text { Program } \\
\text { Pemberdayaan } \\
\end{array}$ \\
\hline \multicolumn{7}{|l|}{ Aspek tata laksana SDM } \\
\hline $\begin{array}{l}\text { Responsibilitas personil } \\
\text { perangkat-perangkat } \\
\text { kelembagaan desa }\end{array}$ & \multirow[t]{3}{*}{ Individu } & (b) & $\begin{array}{l}\text { Pelatihan dan evaluasi reguler kepada } \\
\text { pengurus pemerintah desa, BPD, dan } \\
\text { lembaga kemasyarakatan desa } \\
\text { tentang "etika dan moral pelayan } \\
\text { publik" } \\
\text { Bimbingan dan pendampingan teknis } \\
\text { kepada pengurus pemerintah desa } \\
\text { dalam "menyusun dan menerapkan } \\
\text { sistem pengawasan kegiatan dan } \\
\text { evaluasi kinerja aparat kelembagaan } \\
\text { desa" }\end{array}$ & (a) & $\begin{array}{l}\text { Seluruh pengurus kelembagaan desa } \\
\text { yang lebih profesional dalam } \\
\text { menjalankan fungsi dan administrasi } \\
\text { manajerial birokrasi desa } \\
\text { Terbentuknya sistem pengawasan } \\
\text { kegiatan dan evaluasi kinerja yang } \\
\text { lebih efektif dalam menekan, } \\
\text { mengapresiasi, dan menindak } \\
\text { pengurus-pengurus kelembagaan desa } \\
\text { yang tidak kontributif }\end{array}$ & \multirow[t]{3}{*}{$\begin{array}{l}\text { Peningkatan } \\
\text { kapabilitas } \\
\text { perangkat- } \\
\text { perangkat } \\
\text { kelembagaan } \\
\text { desa }\end{array}$} \\
\hline $\begin{array}{c}\text { Kemampuan inovatif } \\
\text { perangkat-perangkat } \\
\text { kelembagaan desa perihal } \\
\text { pemerintahan dan pelayanan } \\
\text { pembangunan desa } \\
\end{array}$ & & (a) & $\begin{array}{l}\text { Bimbingan dan pendampingan teknis } \\
\text { kepada pengurus pemerintah desa, } \\
\text { BPD, dan lembaga kemasyarakatan } \\
\text { desa tentang "skema-skema modern } \\
\text { dan kreatif dalam pelayanan publik" }\end{array}$ & (a) & $\begin{array}{l}\text { Seluruh pengurus kelembagaan desa } \\
\text { yang lebih kreatif dalam menjalankan } \\
\text { fungsi dan administrasi manajerial } \\
\text { birokrasi desa }\end{array}$ & \\
\hline $\begin{array}{l}\text { Kemampuan pengelolaan } \\
\text { keuangan }\end{array}$ & & (a) & $\begin{array}{l}\text { Pelatihan dan evaluasi reguler kepada } \\
\text { pengurus pemerintah desa, BPD, dan } \\
\text { pengelola BUMDES tentang } \\
\text { "manajemen keuangan dan sistem } \\
\text { penyaluran dan pengawasan } \\
\text { anggaran" }\end{array}$ & (a) & $\begin{array}{l}\text { Seluruh pengurus pemerintah desa, } \\
\text { BPD, dan pengelola Bumdes yang } \\
\text { mampu menerapkan tata kelola } \\
\text { keuangan desa yang transparansi, } \\
\text { akuntabel, dan profesional dalam } \\
\text { perencanaan, pemanfaatan, serta } \\
\text { pengawasan anggaran }\end{array}$ & \\
\hline \multicolumn{7}{|l|}{$\begin{array}{c}\text { Aspek tata laksana } \\
\text { organisasional }\end{array}$} \\
\hline $\begin{array}{l}\text { Konsolidasi internal } \\
\text { kelembagaan }\end{array}$ & \multirow[t]{2}{*}{$\begin{array}{l}\text { Meso atau } \\
\text { kelompok }\end{array}$} & (a) & $\begin{array}{l}\text { Bimbingan dan pendampingan teknis } \\
\text { kepada seluruh kelembagaan di desa } \\
\text { untuk "mereformasi metode dan } \\
\text { sistem saluran komunikasi internal } \\
\text { dan eksternal" }\end{array}$ & (a) & $\begin{array}{l}\text { Terciptanya metode dan sistem } \\
\text { saluran komunikasi internal dan } \\
\text { eksternal bagi kelembagaan di desa } \\
\text { yang efektif, murah, dan mudah }\end{array}$ & \multirow[t]{2}{*}{$\begin{array}{l}\text { Perbaikan } \\
\text { sistem dan tata } \\
\text { kelola internal } \\
\text { kelembagaan }\end{array}$} \\
\hline $\begin{array}{c}\text { Daya tanggap kelembagaan } \\
\text { terhadap kebutuhan } \\
\text { masyarakat }\end{array}$ & & (a) & $\begin{array}{l}\text { Pelatihan reguler kepada seluruh } \\
\text { kelembagaan di desa tentang } \\
\text { "pendataan dan asesmen potensi lokal }\end{array}$ & (a) & $\begin{array}{l}\text { Tercetusnya sistem perencanaan } \\
\text { program yang sesuai dengan standar } \\
\text { perencanaan pembangunan nasional }\end{array}$ & \\
\hline
\end{tabular}


LINDAYASOS: Jurnal IImiah Perlindungan dan Pemberdayaan Vol. 2 No. 1, Juni 2020

\begin{tabular}{|c|c|c|c|c|c|c|}
\hline & & & serta cost benefit analysis" & & $\begin{array}{l}\text { serta mampu mengakomodir beragam } \\
\text { kebutuhan masyarakat desa bagi } \\
\text { kelembagaan di desa }\end{array}$ & \\
\hline \multicolumn{7}{|l|}{ Aspek pengawasan } \\
\hline $\begin{array}{l}\text { Pemantauan keuangan atau } \\
\text { aliran dana }\end{array}$ & Komunitas & $\begin{array}{l}\text { (a) } \\
\text { (b) } \\
\text { (c) } \\
\text { (d) } \\
\text { (e) }\end{array}$ & $\begin{array}{l}\text { Mengadakan program kerja sama } \\
\text { dengan swasta atau komunitas } \\
\text { teknologi atau generasi muda dalam } \\
\text { pemanfaatan teknologi, informasi, } \\
\text { dan komunikasi di kabupaten dan } \\
\text { desa untuk sistem pengawasan dan } \\
\text { penyaluran alokasi dana } \\
\text { Bekerja sama dengan KPK untuk } \\
\text { mempromosikan tindakan } \\
\text { pencegahan korupsi di kabupaten dan } \\
\text { desa } \\
\text { Mengadakan pelatihan media tentang } \\
\text { dana desa di desa-desa untuk } \\
\text { transparansi dan akuntabilitas } \\
\text { Menyelenggarakan forum nasional } \\
\text { dan regional tentang praktik terbaik, } \\
\text { keberhasilan, dan tantangan } \\
\text { penyaluran dan alokasi dana desa di } \\
\text { antara para pemangku kepentingan } \\
\text { Program kemitraan dengan swasta } \\
\text { atau Bumdes untuk menganalisis } \\
\text { potensi dan aset desa sebagai dasar } \\
\text { pembuatan keputusan dalam } \\
\text { pengelolaan aset dan potensi desa } \\
\text { (dampingan khusus untuk BUMDES) }\end{array}$ & $\begin{array}{l}\text { (a) } \\
\text { (b) } \\
\text { (c) } \\
\text { (d) } \\
\text { (e) }\end{array}$ & $\begin{array}{l}\text { Terbentuknya kerja sama } \\
\text { berkelanjutan dalam memanfaatkan } \\
\text { teknologi, informasi, dan komunikasi } \\
\text { guna sistem pengawasan dan } \\
\text { penyaluran alokasi dana } \\
\text { Program rutin tahunan KPK dalam } \\
\text { mengunjungi desa-desa demi } \\
\text { penyuluhan korupsi dan berbagai } \\
\text { hukumannya } \\
\text { Terbuatnya media bersama dengan } \\
\text { pihak luar dalam bentuk cetak } \\
\text { ataupun eletronik untuk melaporkan } \\
\text { ke masyarakat desa dan publik } \\
\text { menyangkut penggunaan dana desa } \\
\text { Program periodik di tingkat nasional } \\
\text { dan regional dalam mengkaji praktik } \\
\text { terbaik penggunaan alokasi dana } \\
\text { demi pembangunan desa } \\
\text { Adanya rencana bisnis kemitraan } \\
\text { yang disusun berdasarkan } \\
\text { perhitungan akuran dan tepat dengan } \\
\text { metode partisipatif; juga adanya } \\
\text { skema pembagian hasil yang adil } \\
\text { dalam kemitraan }\end{array}$ & \multirow[t]{2}{*}{$\begin{array}{c}\text { Optimalisasi } \\
\text { kinerja } \\
\text { kelembagaan } \\
\text { dalam menjaring } \\
\text { mitra }\end{array}$} \\
\hline $\begin{array}{l}\text { Saluran pengaduan } \\
\text { masyarakat desa yang } \\
\text { efektif }\end{array}$ & & (a) & $\begin{array}{l}\text { Mengadakan program kerja sama } \\
\text { dengan swasta atau komunitas } \\
\text { teknologi atau generasi muda dalam } \\
\text { pemanfaatan teknologi, informasi, } \\
\text { dan komunikasi di kabupaten dan } \\
\text { desa sebagai mekanisme saluran } \\
\text { pengaduan masyarakat }\end{array}$ & (b) & $\begin{array}{l}\text { Terbentuknya kerja sama } \\
\text { berkelanjutan dalam memanfaatkan } \\
\text { teknologi, informasi, dan komunikasi } \\
\text { guna mekanisme saluran pengaduan } \\
\text { masyarakat }\end{array}$ & \\
\hline
\end{tabular}




\section{KESIMPULAN}

Hasil penelitian ini menunjukkan ada tiga aspek menyangkut tantangan kelembagaan yang terjadi di Desa Nagarawangi, yakni tantangan aspek tata laksana SDM, tatangan aspek tata laksana organisasional, dan tantangan aspek pengawasan. Aspek tata laksana SDM termasuk dalam persoalan jenjang individu seperti isu responsibilitas personil perangkatperangkat kelembagaan desa, kemampuan inovatif perangkat-perangkat kelembagaan desa perihal pemerintahan dan pelayanan pembangunan desa, dan kemampuaan pengelolaan keuangan. Aspek tata laksana organisasional termasuk dalam persoalan jenjang kelompok seperti isu konsolidasi internal kelembagaan dan daya tanggap kelembagaan terhadap kebutuhan masyarakat. Aspek pengawasan termasuk dalam persoalan jenjang komunitas seperti isu pemantauan keuangan atau aliran dana dan saluran pengaduan masyarakat desa yang efektif.

Adapun dengan menyentuh seluruh jenjang dalam mekanisme pemberdayaan kelembagaan, baik level individu, meso atau kelompok, maupun komunitas, dapat tumbuh struktur dan kultur kelembagaan desa yang transparan, akuntabel, profesional, dan responsif demi mewujudkan kesejahteraan BPS. (2018). Statistik Potensi Desa Indonesia 2018. 2018: Badan Pusat Statistik (BPS).

BPS Kab. Sumedang. (2016). Kecamatan Rancakalong dalam Angka 2016. Kabupaten Sumedang: Badan Pusat Statistik Kabupaten Sumedang.

BPS Kab. Sumedang. (2016b). Statistik Kecamatan Daerah Rancakalong 2016. Kabupaten Sumedang: Badan Pusat Statistik Kabupaten Sumedang.

BPS Kab. Sumedang. (2017). Kecamatan Rancakalong dalam Angka 2017. masyarakat desa yang mandiri dan berkelanjutan.

\section{SARAN}

Penelitian ini menyarankan praktik program pemberdayaan berdasarkan tiga jenjang ini dilakukan berdasarkan urgensinya. Artinya, program yang dilakukan lebih dahulu harus dipertimbangkan berdasarkan kompleksitas isu, jumlah pemangku kepentingan, dan pendanaan.

Dalam hal ini, dalam jangka waktu terdekat, penelitian ini menyarankan mempraktikkan program pemberdayaan yang mampu mengatasi isu "responsibilitas personil perangkat-perangkat kelembagaan desa" dengan program pemberdayaan seperti "pelatihan dan evaluasi reguler kepada pengurus pemerintah desa, BPD, dan lembaga kemasyarakatan desa tentang 'etika dan moral pelayan publik"”. Program ini secara isu tidak begitu rumit, jumlah pemangku kepentingan pun tidak banyak karena bisa hanya dengan melibatkan dukungan akademisi atau praktisi, dan pendanaan pun dapat melalui kerja sama dengan lembaga-lembaga akademis tertentu.

\section{DAFTAR PUSTAKA}

Kabupaten Sumedang: Badan Pusat Statistik Kabupaten Sumedang.

BPS Kab. Sumedang. (2018). Kecamatan Rancakalong dalam Angka 2018.

Kabupaten Sumedang: Badan Pusat Statistik Kabupaten Sumedang.

BPS Kab. Sumedang. (2019). Kecamatan Rancakalong dalam Angka 2019.

Kabupaten Sumedang: Badan Pusat Statistik Kabupaten Sumedang.

BPS Kab. Sumedang. (Statistik Daerah Kabupaten Sumedang 2018). $2018 b$. 
Kabupaten Sumedang: Badan Pusat Statistik Kabupaten Sumedang.

Creswell, J. W. (2003). Research Design: Qualitative, Quantitative, and Mixed Methods Approaches (Second Edition). London: Sage Publications.

Desa Nagarawangi. (2018). Monografi Desa Nagarawangi 2017. Kabupaten Sumedang: Pemerintah Desa Nagarawangi.

Djaha, A. S. (2006). Kapasitas Desa dalam Pelaksanaan Otonomi Desa di Kecamatan Northwest Alor, Kabupaten Alor . Jurnal Administrasi Publik, Vol. 5, No. 1 .

Djaha, A. S. (2007). Desa Adat (Sebuah Upaya Penyelenggaraan Pemerintahan Desa Berdasarkan Adat Istiadat Setempat: Studi Kasus di Desa Bampalola Kecamatan Northwest Alor. Jurnal Pluralis Jurnal Ilmu-Ilmu Sosial, Vol. V, No. 2.

Fahrudin, A. (2012). Pengantar Kesejahteraan Sosial. Bandung: PT Refika Aditama.

Hargita, R. (2015). Partisipasi Lembaga Pemberdayaan Masyarakat Desa dalam Perencanaan Pembangunan Desa (Studi Kasus di Desa Karangwuni, Kecamatan Rongkop). Jurnal Pendidikan Luar Sekolah (Oktober 2015), 1-10.

Muhtarom, A. (2016). Peranan Lembaga Pemberdayaan Masyarakat dalam Pembangunan di Desa, di Kabupaten
Lamongan. Jurnal Penelitian Ekonomi dan Akuntansi, Vol. 1, No. 3, 181-204.

Nasrul, W. (2013). Peran Kelembagaan Lokal Adat dalam Pembangunan Desa. Jurnal Ekonomi Pembangunan, Vol. 14, No. 1, 102-109.

Prasetyono et al. (2017). Pemberdayaan Petani Berbasis Modal Sosial dan Kelembagaan. Asian Journal of Innovation and Entrepreneurship, Vol. 2, No. 3, 231-238.

Puskapol Fisip UI. (2016). Tata Kelola Desa yang Partisipatif, Adil, dan Setara. Depok: Pusat Kajian Politik Fakultas Ilmu Sosial dan Ilmu Politik Universitas Indonesia.

Sudjatmiko, B. (2014). Pemberdayaan Masyarakat, Pembangunan Desa, dan Pembangunan Kawasan Perdesaan Berdasarkan Undang-Undang Desa. Jakarta: The Indonesian Institute.

Suharto, E. (2005). Membangun Masyarakat Memberdayakan Rakyat. Bandung: PT Refika Aditama.

Wicaksono, B. (2016). Penguatan Kapasitas Kelembagaan Desa: Concept Note. Jurnal Administrasi Publik, Vol. 15, No. 2.

Zimmerman, M. A. (2010). Empowerment Theory (Psychological, Organizational, and Community Level of Analysis). Dalam J. Rappaport, \& E. Seidman, Handbook of Community Psychology (hal. 43-63). New York: Plenum Publishers. 